\title{
Determinants of Environmental Performance with the Carbon Management Strategy as an Intervening Variable
}

\author{
Lince* Yvonne Augustine \\ Faculty of Economic and Business, Trisakti University, Jakarta, Indonesia
}

\begin{abstract}
The purpose of this study is to examine the determinants of environmental performance with carbon management strategy as mediation. Environmental management system, environmental committee, number of director meetings, director's educational background are dependent variables. Environmental performance as dependent variable, carbon management strategy is an intervening variable. In Addition, three control variables are: Firm age, Firm size, and leverage. This study using the population of companies that publish sustainability reports from 20142016,exwith 82 research objects. From this study found that environmental management system, environmental committee, number of director meetings and the directors' educational background did not have a positive effect on environmental performance. However, after the mediation of the carbon management strategy, the independent variables all had a positive effect on environmental performance. Thus, it is found that companies that have carbon management strategies will encourage better environmental performance so that they can mitigate greenhouse gases. This study implications for corporate leaders are expected to be able to implement a carbon management strategy to improve better Environmental Performance. Practitioners and the public should be followed to take care of the environment and be more obedient and participate in realizing government regulations regarding house gas mitigation for the preservation of the earth.
\end{abstract}

Keywords: Environmental Performance, Environmental Management System, Environmental Committee, Number of Director Meetings, Director's Educational Background and Carbon Management Strategy

DOI: $10.7176 / \mathrm{JESD} / 10-7-07$

Publication date: April $30^{\text {th }} 2019$

\section{Introduction}

The earth is a place where living things reproduce and harmonize with a good ecosystem. Climate change results in disruption of the preservation of living things because they are dangerous both for the survival of humans and other living things. This climate change occurs due to the presence of geothermal energy. This problem must be dealt with seriously because it can cause major disasters on earth and its sustainability. The World Meteorological Organization (WMO) reports atmospheric CO2 concentrations soaring and $\mathrm{CO} 2$ levels now 145 percent higher than pre-industrial levels (https://www.voaindonesia.com/a/pbb-emisi-gas-rumah-kaca-tertinggi-dalam-800ributahun/4093328.html). Gases categorized as GHGs are Carbon Dioxide(CO2), Methane (CH4), Nitrous Oxide (N2O), Hydrofluorocarbons (HFCS), Perfluorocarbons (PFCS) and Sulfur hexafluoride (SF6), (Irwhantoko 2016).

The Kyoto Protocol was signed in Kyoto, Japan on December 11, 1997 which was adopted from the highlevel convention of the earth in Rio De Janeiro, Brazil. The Kyoto Protocol came into force in 2005, this is an effort made by the United Nations to reduce global warming "namely the stabilization of greenhouse gas concentrations in the atmosphere at a level that can prevent human / anthropogenis interference in the world climate (www.mongabay.co.id>cop-18 COP-18 Doha: Negara-Negara Maju Lepas Tangan dari Protokol Kyoto). From the Kyoto Protocol conference to the Paris Agreement conference which was the COP-21 concerning mitigation of greenhouse gas emissions, adaptation and finance. Paris Agreement was signed by 194 countries and 141 countries that ratified the agreement and is expected to be effective in 2020. "Indonesia is one of the countries that signed this agreement on April 22, 2016. The percentage of greenhouse gases ratified by Indonesia is $1.49 \% "$ (Https://www.ojk.go.id Paris Agreement). The Financial Services Authority is a government body that not only helps manage the flow of funds and is low in greenhouse gas emissions in accordance with the Paris Agreement signed by the Indonesian government

Companies should have carbon management strategies to reduce greenhouse gases caused by company activities. Environmental sustainability plays an important role for the survival of humans and other creatures. Research by Wahyuni and Ratnatunga (2015) investigated carbon strategies and carbon management adopted from companies that differed in level from Australia's national energy market. Danish Firm's adoption of green strategy (Hamid Moini, 2014) is a study that aims to examine the issue of corporate environmentalism from a managerial perspective, specifically related to top management commitment and competitive advantage, which are put together for decision making for environmental strategies.

Carbon management strategy is one of the sustainability strategies that can improve good environmental performance. Especially in Indonesia as developing Country was found that volume of carbon emission and carbon disclosure emission were not related with firm value, but carbon management practice has positive relationship with firm value (Sudibyo YA, 2018). A longitudinal study that examined the determinants of the adoption of a 
carbon management strategy among 200 top companies registered in Australia (Yunus et al., 2016). Other research investigates the relationship between environmental management systems and environmental performance (Melayk et al., 2003).

This study is to examine the determinants that influence environmental performance by paying attention to companies that have carbon management strategies. These factors consist of company internal factors, namely the environmental management system, corporate governance factors, namely the Environmental Committee, Number of Director 'Meetings, Directors' Educational Background. This study also has several control variables, among others: Firm age, Firm size and leverage. This research is to examine whether companies that have carbon management strategies will have better environmental performance. The carbon management strategy also encourages companies to follow the regulations set by the government for the purpose of mitigating greenhouse gases for the sake of environmental sustainability and the sustainability of life on earth.

\section{Literature Review}

\subsection{Legitimacy and Stakeholder Theory}

Legitimacy theory as a basis for explaining the existence of companies that pay attention to the environment and society so that the company can still operate. Yunus et al. (2016) said that a legitimacy theoretical framework was adopted to investigate whether there was a significant relationship between the company's decision to adopt carbon management strategies and organizational internal factors such as the presence of an environmental management system. Company management such as having an environmental committee, the size of the board and an independent board. Lash and Willington (2007) identify various specific risks that emit carbon and cause climate change for organizations.

Whereas, Stakeholder Theory is closely related to Stakeholder interests on various information of a company or organization for decision making. Stakeholders are not only shareholders, but also all stakeholders of the company both board of directors, employees, suppliers, consumers, investors, lenders and the government. The challenges inherent in the sustainability of business development are built on the management capabilities of stakeholders, environment, social and governance performance (Carol-Ann Tetrault Sirsly, 2015). The carbon management strategy owned by the company can influence environmental performance better so that interested parties in the company that manage internally such as the board and employees as well as external parties such as investors and lenders will be more confident to invest and provide funds for the management of the company because better environmental performance will better guarantee the company's overall performance.

\subsection{Environmental Management system}

Companies that care about the environment are created through an environmental management system owned by the company. Good environmental management system will improve the company's environmental performance. Ivan Montiel and Bryan W, Husted (2009) say that institutions in the past to add environmental performance are voluntary environmental management programs. In the present, many certificates are designed and practiced which are the company's environmental management programs. Research on investigating the relationship between environmental management systems and environmental performance (Melayk et al., 2003). The results of other studies stated that organizational strategy, structure, Environmental Management Accounting (EMA), Company size, technology and environmental uncertainty were found to be positively associated with CMA adoption (Nartey E, 2018).

\subsection{Environment Committee}

Environment Committee functions to give consideration to efforts to prevent the impact of matters related to environmental issues. A company with an environmental committee shows evidence from governance to direct the organization's long-term strategy towards carbon in the future, reducing business risk (Rankin et al., 2011). Companies that adopt the carbon management strategy are more environmental committees and this research that says that the age of the company is associated with the adoption of a company's carbon management strategy (Yunus et al., 2016).

\subsection{Number of Director Meetings}

Director's meetings can take place if they have been attended by the majority of the board of directors. The number of board meetings determines both financial performance and environmental performance. The increasing number of board meetings will further enhance environmental performance. Research on board meetings has a positive effect on the company's financial performance and that educational background had a negative effect on financial performance ( Dwi .S and Ningrum .K (2017).

\subsection{Director's Educational Background}

The educational background of the commissioners of business commissioners has a significant effect on the value 
of the company in the implementation of Good Corporate Governance in BUMN companies (Rahayu .S and Nugroho .S, 2014). Research by Septiadika Dwi and Kartika Ningrum (2017), said that educational background had a negative effect on financial performance.

\subsection{Carbon Management Strategy}

Companies that care about the environment, the company is expected to have a carbon management strategy so that it can reduce greenhouse gases. There have been several studies conducted on the carbon management strategy. Research on the determinants of adoption of a carbon management strategy says that companies that adopt CMS have an EMS, an environmental committee, a larger board size, and a larger independent board (Yunus et al.,2016).The results of other studies stated that organizational strategy, structure, Environmental Management Accounting (EMA), Company size, technology and environmental uncertainty were found to be positively associated with CMA adoption (Nartey E, 2018).

\subsection{Environmental Performance}

The Company's adherence to government regulations is a manifestation of Indonesia's participation with the United Nations regarding the reduction of greenhouse gases due to the inhumanity of the environment. There are factors that determine the increase in environmental performance. The high level of pollution from GHG emissions has a negative effect on carbon disclosure information. Companies with good environmental performance will be more informed of carbon in company disclosures (Grigoris .G at al., 2017).A study of environmental management and improving environmental performance through human resources and comparative advantage (Adnandale et al., 2004).

\subsection{Firm Age}

The firm age is the length of time the company was founded. The number of years the company has been operated from since the company existed. Many researchers are researching the age of the company. One of them is research that says that the age of the company is associated with the adoption of a company's carbon management strategy. (Yunus et.al, 2016), Another study said that the age of the company is not significant with the adoption of carbon management accounting (Nartey E, 2018).

\subsection{Firm Size}

The firm size are determined by their size. The firms can be done in many ways to find out the size of the company. The size of this company can be through assets, the number of workers and the number of sales or income received by a company or from the number of shares outstanding. Companies that have greater credibility to disclose information on GHG emissions (Rankin et al., 2011). The size of the company is also positively associated with the adoption of carbon management accounting (Nartey E, 2018).

\subsection{Leverage}

Leverage is a ratio used to measure total debt with total assets at the end of the fiscal year (Clarkson et.al., 2006). So, leverage can be interpreted as the ability of a company to repay a loan compared to the amount of assets the company has. Research that says that leverage is positively associated with the adoption of a carbon management strategy (Yunus et al., 2016) and Leverage suggests that companies with higher credibility will express GHGs (Rankin et al., 2011).

\section{Research Methods \\ 3.1 Sample}

The sample of this study is the company that publishes a sustainability report with a list of company populations sourced from sra.ncsr-id.org and https://datacenteraid.blogspot.co.id.Thus, the web of each company using sustainability reports and annual reports company. This research is 2014, 2015 and 2016, with 82 research objects. This study used Multiple Regression method and SPSS version 22.

\subsection{Conceptual Framework}

The conceptual framework from this study is described as the following framework: 


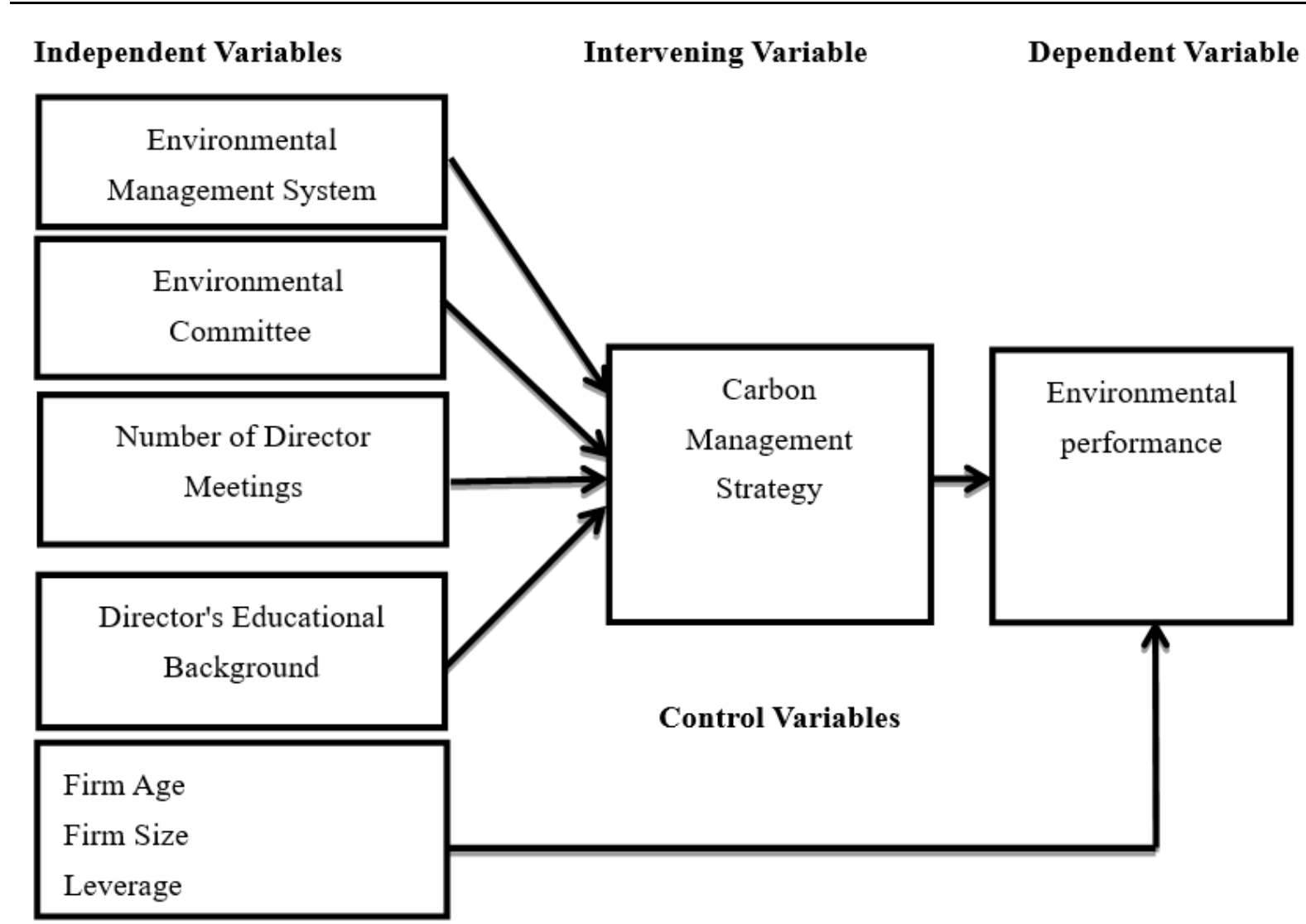

Source : Made by the Researcher

\subsection{Measurement of Variables}

\subsubsection{Independent Variable}

Independent variables consist of environmental management systems, environmental committees, number of board meetings and educational backgrounds of directors. An environmental management system (EMS) is a systematic process for determining, implementing and examining various environmental goals, policies and accountability (Yunus et al.,2016). The measurement is through a certificate from the Ministry of Environment (PROPER) regarding or ISO 14001 (International Organization for Standardization on environmental management) that is owned by the company using dummy variables, Certified $=1$ and no $=0$. An Environment Committee (EC) is a Committee that is responsible for managing corporate environmental risks, including environmentally related risks of reputation and legitimacy threats (Yunus et al.,2016). The measurement is based on the existence of an environmental committee within the company. If the firm have a committee $=1$, if not $=0$.

The directors must hold meeting periodically at least 1 (one) time in each month. Directors' meetings can take place if they have been attended by the majority of the directors (POJK number 33 / POJK.04.2014). The number of director meetings (Number of DM) in 1 year compared to 12 times. The number of director meetings required is based on regulations from the Financial Services Authority (OJK). The director's educational background (DEB) in this study is the directors who have an Accounting education background. The measurement is by the number of directors who have Accounting education compared to the total number of directors.

\subsubsection{Intervening}

The Sustainability reporting give information relating to climate change and carbon strategies. Measurements used in measuring carbon management strategies (CMS) using the criteria used to identify companies have carbon management strategies namely product innovation, technology innovation, process innovation, energy efficiency initiatives. Participation in emissions trading and carbon offset initiatives. This criterion was adopted from Yunus Somaiya at al. (2016) and Nartey Edward (2018) with the following definition:

- Product Innovation: designing new products that emit less carbon or develop existing products that are carbon free during their production and / or use.

- Technology Innovation: Changing technology process to improve greenhouse gas inventories

- Process Innovation: Development of new production processes that lack carbon emission or the development of existing production processes to be carbon free.

- Energy Efficiency Initiative: promoting energy efficiency projects, substituting energy resources with 
clean fuels that reduce direct emissions from greenhouse gases.

- Participation in Emissions trading: Obtain additional carbon reduction capacity by participating in carbon trading schemes.

- Carbon offset Initiative : Investment in projects offset carbon

Measurements used in measuring carbon management strategies. Comparison of the number of criteria owned by the company compared to the total existing strategies.

\subsubsection{Dependent Variable}

The variable dependent uses environmental performance. According to Surato et al. environmental performance (EP) is the performance of the company in creating a green environment (pustakabakul.blogspot.com Pengertian Kinerja dan Pengukuran Kinerja Lingkungan). Measuring environmental performance using natural logs of total carbon dioxide is calculated as a metric ton of GHG.

\subsubsection{Controls Variables}

Firm age, Firm size and leverage are control variables. The age of the Firm is the number of years the firm has operated since the firm existed. (Nartey E, 2018). The measurement uses the number of years the Firm has since the Firm exists or is operated. The size of the company receives attention from group variations and greater pressure to express social and environmental activities in the legitimacy of business (Yunus at al., 2016). The measurement uses the natural log of total revenue. Whereas Leverage is a ratio used to measure total debt with total assets at the end of the fiscal year (Clarkson et al., 2006).

\section{Research Results}

4.1 Descriptive statistic

Table 4.1 Descriptive statistics

Descriptive Statistics

\begin{tabular}{|l|l|l|l|}
\hline & Mean & Std. Deviation & N \\
\hline EP & 14.185 & 2.3078 & 82 \\
EMS & .87 & 343 & 82 \\
EC & 94 & 241 & 82 \\
Number of DM & 2.284 & 1.3968 & 82 \\
DEB & .185 & 1095 & 82 \\
CMS & .717 & 1314 & 82 \\
Firm Age & 47.915 & 26.4179 & 82 \\
Firm Size & 16.451 & 1.6756 & 82 \\
leverage & .514 & 2044 & 82 \\
\hline
\end{tabular}

Table 4.1 for the regression model, the average company emits CO2 of 14,185,000 tons per year when the company carries out its business activities. From this table, 87 percent of companies have an environmental management system. Furthermore, 94 percent of companies have environmental committees. Meetings of company directors in creating environmental performance on average about 26 meetings in one year with 2.2 times the number of meetings that have been determined 12 times in one year. Directors with accounting education are on average $18 \%$ or it can be said that average 1 in 5 directors of a company has a director who has accounting education. The company's debt can be borne by the company's assets on average 51 percent. The average sales is around IDR. 16,451,000,000,000 companies every year. The average age of the firm is 47 years. While the average carbon management strategy is owned by the company, around $71.7 \%$ in creating environmental performance.

\subsection{Normality test}

Graph 4.1 Normal P-P Plot of Regression Standardized Residual

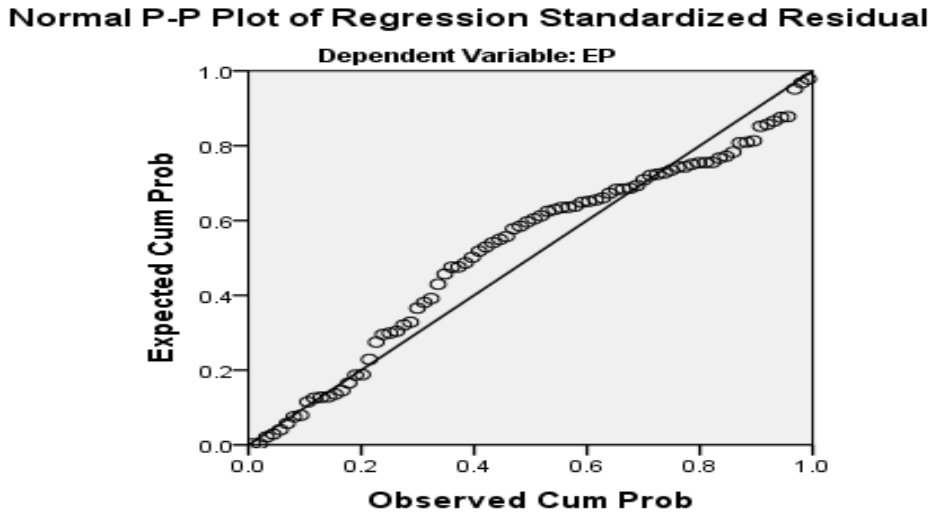


The normal graph of P-P Plot of Standardized Residual Regression shows that a decent model is used to predict environmental performance based on independent variables because the points spread around the diagonal line and the distribution follows the direction of the diagonal line which means that the data is normally distributed.

\subsection{Classic assumption test}

\subsubsection{Autocorrelation Test}

Table 4.2 Autocorrelation Test

\section{Model Summary}

\begin{tabular}{|l|l|l|l|l|l|}
\hline Model & $\mathrm{R}$ & R Square & Adjusted R Square & $\begin{array}{l}\text { Std. Error of the } \\
\text { Estimate }\end{array}$ & Durbin-Watson \\
\hline 1 & $.583^{\mathrm{a}}$ & .340 & 268 & 1.9749 & 2.053 \\
\hline
\end{tabular}

a. Predictors: (Constant), leverage, DEB, CMS, Firm Age, Firm Size, EMS, Number of DM, EC

b. Dependent Variable: EP

Table 4.2 this regression model shows the Durbin Watson number of 2.053. This indicates the occurrence of negative autocorrelation because the Durbin Watson value is above +2 .

\subsubsection{Multicollinearity Test}

Table 4.3 Multicollinearity Test

\section{Coefficients}

\begin{tabular}{|c|c|c|c|c|c|c|c|}
\hline \multirow[b]{2}{*}{ Model } & \multicolumn{2}{|c|}{ Unstandardized Coefficients } & \multirow{2}{*}{$\begin{array}{l}\text { Standardized Coefficients } \\
\text { Beta }\end{array}$} & \multirow[b]{2}{*}{$\mathrm{t}$} & \multirow[b]{2}{*}{ Sig. } & \multicolumn{2}{|c|}{ Collinearity Statistics } \\
\hline & $\mathrm{B}$ & Std. Error & & & & Tolerance & VIF \\
\hline 1(Constant) & 8.568 & 2.625 & & 3.264 & .002 & & \\
\hline EMS & .838 & .692 & .125 & 1.211 & .230 & .856 & 1.168 \\
\hline $\mathrm{EC}$ & .294 & 1.099 & .031 & .268 & .790 & .687 & 1.455 \\
\hline Number of DM & -.217 & .179 & -.131 & -1.213 & .229 & .770 & 1.298 \\
\hline DEB & 4.075 & 2.204 & .193 & 1.849 & .068 & .826 & 1.210 \\
\hline CMS & 1.919 & 1.946 & .109 & .986 & .327 & .736 & 1.359 \\
\hline Firm Age & -.014 & .009 & -.156 & -1.566 & .122 & .910 & 1.099 \\
\hline Firm Size & .346 & .142 & .252 & 2.447 & .017 & .856 & 1.169 \\
\hline leverage & -4.019 & 1.173 & -.356 & -3.426 & .001 & .837 & 1.194 \\
\hline
\end{tabular}

a. Dependent Variable: EP

Table 4.3 shows that Independent with environmental performance as dependent variable has a VIF value from the lowest value of 1.168 and the highest of 1.455 . The lowest tolerance value is 0.687 and the highest is 0.910. Based on the VIF value it is said that multicollinearity is free if the VIF value is below 10 and the tolerance value is more than 0.100 . Based on table 4.3 each variable has a VIF number of less than 10 and a tolerance value of more than 0.100 , then the regression model in this study did not occur multicollinearity.

\subsubsection{Heteroscedasticity Test}

Graph 4.2. Heteroscedasticity Test

\section{Scatterplot}

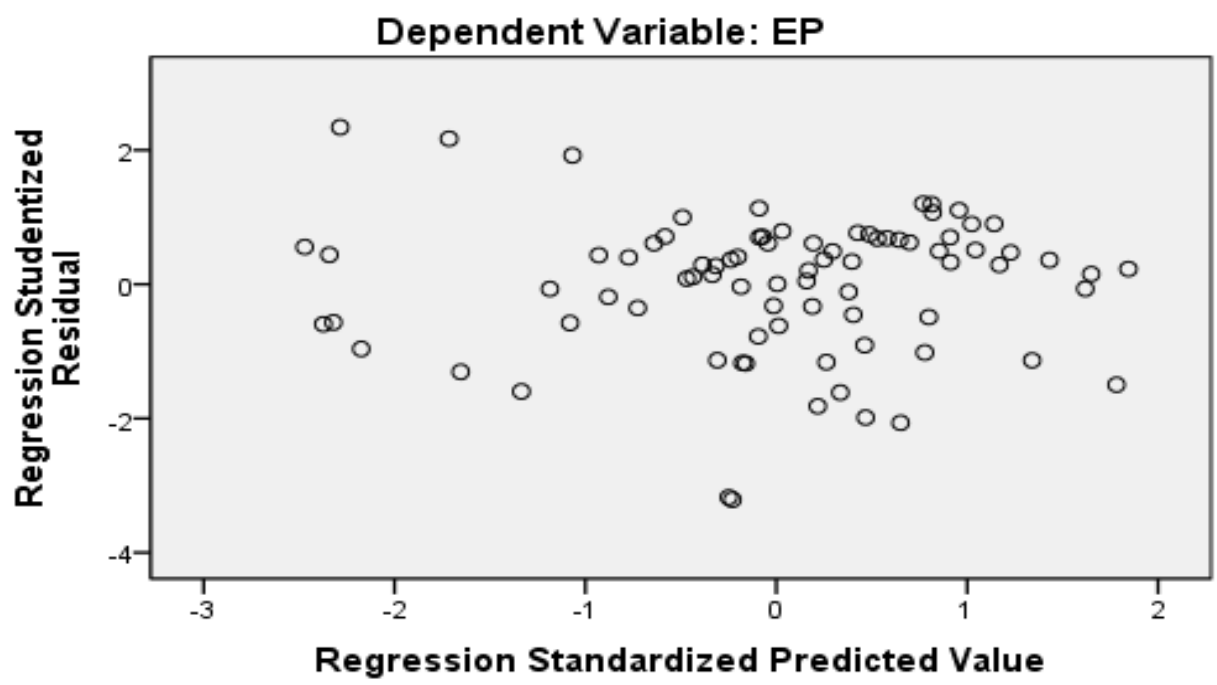


Based on the graph Heteroscedasticity both graph 4.2 the regression model is seen to spread randomly not forming a certain pattern clearly, and spread both above and below the number 0 on the $\mathrm{Y}$ axis. Thus the regression model does not experience heteroscedasticity.

\subsection{Test of Hypothesis}

\subsubsection{F Test}

Table 4.4 ANOVA Tables

ANOVA

\begin{tabular}{|ll|r|r|r|r|r|}
\hline Model & Sum of Squares & df & Mean Square & F & Sig. \\
\hline 1 & Regression & 146.682 & 8 & 18.335 & 4.701 & $.000^{*}$ \\
& Residual & 284.717 & 73 & 3.900 & & \\
& Total & 431.398 & 81 & & & \\
\hline
\end{tabular}

a. Dependent Variable: EP

b. Predictors: (Constant), leverage, DEB, CMS ,Firm Age, Firm Size, EMS, Number of DM, EC

Note: significant at the 0.05 (one-tailed)*

The $\mathrm{F}$ test results from the ANOVA table have a significant number of 0,000 . The independent variable when tested together influences the environmental performance, namely environmental management system, environmental committee, number of director meetings and the director's educational background have a positive effect on environmental performance .

\subsection{2. $T$ Test}

Table 4.5 T Test Tables (Test variable $\mathrm{X}$ against Variable $\mathrm{Y}$ )

\section{Coefficients}

\begin{tabular}{|c|c|c|c|c|c|}
\hline \multirow[b]{2}{*}{ Model } & \multicolumn{2}{|c|}{ Unstandardized Coefficients } & \multirow{2}{*}{$\begin{array}{l}\text { Standardized Coefficients } \\
\text { Beta }\end{array}$} & \multirow[b]{2}{*}{$t$} & \multirow[b]{2}{*}{ Sig. } \\
\hline & $\mathrm{B}$ & Std. Error & & & \\
\hline 1 (Constant) & 8.568 & 2.625 & & 3.264 & .002 \\
\hline EMS & .838 & .692 & .125 & 1.211 & .230 \\
\hline $\mathrm{EC}$ & .294 & 1.099 & .031 & .268 & .790 \\
\hline Number of DM & -.217 & .179 & -.131 & -1.213 & .229 \\
\hline DEB & 4.075 & 2.204 & .193 & 1.849 & .068 \\
\hline CMS & 1.919 & 1.946 & .109 & .986 & .327 \\
\hline Firm Age & -.014 & .009 & -.156 & -1.566 & .122 \\
\hline Firm Size & .346 & .142 & .252 & 2.447 & $.017 *$ \\
\hline leverage & -4.019 & 1.173 & -.356 & -3.426 & $.001 *$ \\
\hline
\end{tabular}

a. Dependent Variable: EP

Note: significant at the 0.05 (one-tailed)*

Based on the T Test Table, namely the X Variable Test table against Y, the test results are obtained as follows: environmental management system with a significant value of 0.230 ; environmental committee with a significant value of 0.790 . The number of director meetings with a significant value of 0.229 . The director's educational background with a significant value of 0.068 . From the results of this study that environmental management system, environmental committee, number of director meetings, and directors' educational background did not have a positive effect on environmental performance

Table 4.6 T Test Tables (Test Variable X for Variable Z)

Coefficients

\begin{tabular}{|c|c|c|c|c|c|}
\hline \multirow[b]{2}{*}{ Model } & \multicolumn{2}{|c|}{ Unstandardized Coefficients } & \multirow{2}{*}{$\begin{array}{l}\text { Standardized } \\
\text { Coefficients } \\
\text { Beta }\end{array}$} & \multirow[b]{2}{*}{$\mathrm{t}$} & \multirow[b]{2}{*}{ Sig. } \\
\hline & $\mathrm{B}$ & Std. Error & & & \\
\hline (Constant) & .415 & .068 & & 6.062 & .000 \\
\hline EMS & .057 & .040 & .148 & 1.432 & .156 \\
\hline $\mathrm{EC}$ & .250 & .058 & .457 & 4.294 & $.000^{*}$ \\
\hline Number of DM & .017 & .010 & .177 & 1.721 & .089 \\
\hline DEB & -.103 & .125 & -.086 & -.820 & .415 \\
\hline
\end{tabular}

a. Dependent Variable: CMS

Note: significant at the 0.05 (one-tailed)*

Table 4.6 regarding the Test of variable $\mathrm{X}$ to $\mathrm{Z}$, the test results are obtained as follows: environmental management system with a significant number of 0.156 . An environmental committee with a significant number 
of 0,000 . The Number of director meetings with a significance number of 0.089 . The director's educational background with significant figures of 0.415 . An environmental management system, number of director meetings and directors' educational background. They have not a positive effect on the carbon management strategy. Meanwhile, the environmental committee has a positive effect on carbon management strategies.

\subsection{Path Analysis}

Path analysis is used to determine the role of Intervening variable. The purpose of path analysis is to explain the result of a direct and indirect set of variables, as a causal variable for the variable effect (Kristaung.R and Augustine.Y, 2018). Does the Intervening variable play a role in influencing the independent variables on the dependent variable using regression coefficients in table 4.5 and table 4.6. Then, researcher find out the Mediation role of Variable $\mathrm{Z}$.

Table 4.7 Fully and Partly Mediation

\begin{tabular}{|l|l|l|l|l|l|l|}
\hline variables & $\begin{array}{l}\text { Regression } \\
\text { Coefficient } \\
\text { X to Y } \\
\text { (Alpha) }\end{array}$ & $\begin{array}{l}\text { Regression } \\
\text { Coefficient } \\
\text { X to Z } \\
\text { (Beta) }\end{array}$ & $\begin{array}{l}\text { Multiplication } \\
\text { (Alpha) } \\
\text { with } \\
\text { (Beta) }\end{array}$ & $\begin{array}{l}\text { Regression } \\
\text { Coefficient } \\
\text { Z to Y } \\
\text { (Theta) }\end{array}$ & $\begin{array}{l}\text { There is a } \\
\text { mediating role } \\
\text { if Theta }>\text { Alfa } \\
\text { multiplication } \\
\text { with beta }\end{array}$ & $\begin{array}{l}\text { Mediation } \\
\text { Level }\end{array}$ \\
\hline EMS & 0,838 & 0.057 & 0,047 & 1,919 & $\begin{array}{l}\text { There is } \\
\text { mediation }\end{array}$ & $\begin{array}{l}\text { Full } \\
\text { Mediation }\end{array}$ \\
\hline EC & 0,294 & 0,250 & 0,073 & 1,919 & $\begin{array}{l}\text { there is } \\
\text { mediation }\end{array}$ & $\begin{array}{l}\text { Part } \\
\text { Mediation }\end{array}$ \\
\hline $\begin{array}{l}\text { Number } \\
\text { of DM }\end{array}$ & 0,217 & 0,017 & 0,003 & 1,919 & $\begin{array}{l}\text { there is } \\
\text { mediation }\end{array}$ & $\begin{array}{l}\text { Full } \\
\text { Mediation }\end{array}$ \\
\hline DEB & 4,075 & 0,103 & 0,419 & 1,919 & $\begin{array}{l}\text { there is } \\
\text { mediation }\end{array}$ & $\begin{array}{l}\text { Part } \\
\text { Mediation }\end{array}$ \\
\hline
\end{tabular}

Source : Made by the Researcher

Based on the path analysis table 4.7 the mediating variable or intervening is the carbon management strategy. The influence of environmental management systems on environmental performance is mediated by carbon management strategies. From the research data the results of the multiplication of the regression coefficient between the coefficients of $X$ to $Y$ with $X$ to $Z$ are 0.047 . Meanwhile, the $Z$ coefficient of $Y$ is 1,919 . This value is higher than 0.047 . So, there is a role for carbon management strategies that mediate between the influence of the environmental management system and environmental performance. Then the value of 0.047 after there is a full mediation role compared to 0.838 which is a direct test between $\mathrm{X}$ and $\mathrm{Y}$.

The Environment Committee on environmental performance is mediated by the carbon management strategy. From the research data the results of the multiplication of the regression coefficient are 0.073 . The results of the multiplication of the regression coefficients number of directors Meeting are 0.0032 . The director's educational background have a multiplication of regression coefficients 0.419 . The carbon management strategies play a role in reducing these four independent variables environmental performance. The company will further improve environmental performance by implementing carbon management strategies.

\subsection{Discussion}

$\mathrm{H} 1$ proposed is an environmental management system that has a positive effect on environmental performance. However, the proposed $\mathrm{H} 1$ was rejected. The results of this study are not consistent with the research conducted by Rankin et al. (2011) who say that companies voluntarily disclose GHGs that have EMS (Environmental Management System) compared to companies without EMS. Companies that have a good management system will improve environmental performance. This research is also inconsistent with research on investigating the relationship between environmental management systems and environmental performance (Melayk et al., 2003). The results of this study failed to prove the positive influence between environmental management systems on environmental performance.

$\mathrm{H} 2$ proposed is the environment committee that has a positive effect on environmental performance. However, the proposed $\mathrm{H} 2$ was rejected. The results of this study are not consistent with the research conducted by Anandale et al. (2004) where the presence of environmental committees heightened environmental reputation. This research is also not consistent with the existence of an environmental committee to improve environmental performance and good reputation in the company. Companies that have institutions such as environmental committees provide more disclosure of credibility (Rankin et.al., 2011). The results of this study failed to prove the existence of a positive influence between environmental committees on environmental performance.

The proposed $\mathrm{H} 3$ is the number of director meetings positive influential on environmental performance. However, the proposed $\mathrm{H} 3$ was rejected. The results of this study are not consistent with the research conducted by Dwi.S and Ningrum .K (2017), they research on board meetings has a positive effect on financial performance. 
This study does not prove a positive influence between the number of board meetings on environmental performance.

The proposed H4 is the Director.s educational background with a positive influence on environmental performance. However, the proposed H3 was rejected. The results of this study are consistent by Septiadika Dwi and Kartika Ningrum (2017), saying that educational backgrounds negatively affect financial performance. However, inconsistent other studies say that the education background of the commissioners of business commissioners has a significant effect on corporate value in the implementation of Good Corporate Governance in BUMN companies (Rahayu .S and Nugroho .S, 2014). This study did not succeed in proving a positive influence between the director's educational background on environmental performance.

The proposed H5 is a Carbon Management Strategy that has a positive effect on environmental performance. However, the proposed H5 was rejected. This research is not consistent with the research conducted by Yunus Somaiya et al.(2016) that companies that adopt a carbon management strategy (CMS) have more of an Environmental Management System (EMS). This research is also not consistent with other studies, namely investigating the relationship between the application of environmental management systems and performance (Anandale et.al.). This research is also inconsistent with research conducted on companies with good environmental performance that will better inform carbon in company disclosures (Grigoris Giannarakis et al., 2017). This study failed to prove the positive influence between carbon management strategies on environmental performance.

The proposed H6 is an environmental management system that has a positive effect on the carbon management strategy. However, the proposed H6 was rejected. This research is not consistent with the presence of an environmental management system that the company will adopt a carbon management strategy (Yunus et al., 2016). This research is also inconsistent with research conducted on companies in Ghanaian that environmental management accounting is positively associated with adoption of carbon management accounting (Nartey E, 2018). This study failed to prove the positive influence between environmental management systems on carbon management strategies.

The proposed $\mathrm{H} 7$ is an environment committee that has a positive effect on the carbon management strategy. In this study the proposed $\mathrm{H} 7$ was accepted, this study is consistent with research on the determinants of adoption of carbon management strategies saying that companies that adopt CMS have more EMS, environmental committees, larger board size, and a larger independent board (Yunus et al., 2016). This study successfully proved the positive influence between the environmental committee on carbon management strategies.

The proposed $\mathrm{H} 8$ is the number of directors meetings that have a positive effect on the carbon management strategy. However, the proposed H8 was rejected. This study failed to prove the positive influence between the number of director meetings on carbon management strategies. The number of director meetings in accordance with OJK regulations should be fulfilled, the directors will discuss the company's management strategy more often for the survival of the company.

H9 submitted is the director's educational background has a positive effect on the carbon management strategy. However, the proposed H9 was rejected. This study failed to prove the positive influence between the directors' educational background on carbon management strategies. Companies with good environmental performance will be more informed of carbon in company disclosures (Grigoris Giannarakis at al., 2017). This research is about Adopting carbon management accounting. Therefore, researchers use accounting education as the background of directors in relation to carbon accounting.

The proposed H10 is a carbon management strategy mediating the influence of environmental management systems on environmental performance. In this study the proposed H10 was accepted. This study is consistent with the research conducted by Rankin et al. (2011) who say that companies voluntarily disclose GHGs that have EMS (Environmental Management System) compared to companies without EMS. This study is also consistent with the research conducted by Ivan Montiel and Bryan W, Husted (2009) said that institutions in the past to add environmental performance were voluntary environmental management programs. Other research conducted in Australia is also consistent with this study, the environmental management system has an effect on carbon management strategies. This research is also consistent with research conducted by (Yunus et al .,2016), this study shows that the presence of an environmental management system will adopt a carbon management strategy. The same is the case with research conducted at companies in Ghanaian that environmental management accounting positively associates with the adoption of carbon management accounting (Nartey E, 2018). This study successfully proved that the carbon management strategy mediates the influence of environmental management systems on environmental performance

H11 proposed is a carbon management strategy mediating the influence of the environmental committee on environmental performance. In this study the proposed $\mathrm{H} 11$ was accepted. This research is consistent with research on the presence of environmental committees enhancing environmental reputation (Anandale et al., 2004). This research is also consistent with research on the existence of environmental committees to improve environmental performance and good reputation in the company. Companies that have institutions such as environmental 
committees provide more disclosure of credibility (Rankin et al., 2011). This study successfully proved that the carbon management strategy mediates the influence of the environmental committee on environmental performance

The proposed $\mathrm{H} 12$ is a carbon management strategy mediating the influence of the number of director meetings on environmental performance. In this study the proposed H12 was accepted. This research is consistent with research on board meetings that have a positive effect on financial performance ( Dwi .S and Ningrum .K (2017). The number of board meetings determines good corporate performance including financial performance and environmental performance. The directors' meetings will also determine carbon management strategies to reduce impacts damage and environmental hazards due to company activities so that environmental performance is better. The research successfully proved that carbon management strategy mediates the influence of the number of directors' meetings on environmental performance

The proposed H13 is a carbon management strategy mediating the influence of the director's educational background on environmental performance. In this study the proposed H13 was accepted. This research is consistent with research by Dwi .S and Ningrum .K (2017) say that educational backgrounds negatively affect financial performance. This research is also consistent with other studies, saying that the educational backgrounds of commissioner business commissioners have a significant effect on corporate value in the implementation of good corporate governance in BUMN companies (Rahayu.S and Nugroho.S, 2014). This study successfully proved the carbon management strategy mediates the influence of the directors' educational background on environmental performance

\section{Conclusions, limitations and implications 5.1 Conclusions}

The management system does not have a positive effect on environmental performance because companies that do not have certificates from the Ministry of Environment or ISO 14000 also have good environmental performance. Almost all companies have environmental committees, although their environmental performance is not good. The number of director meetings does not have a positive effect because when the directors meeting does not discuss environmental performance directly but discusses other matters from the company. Meanwhile, the director's educational background can be caused by differences in the background of the directors' education or the existence of Financial Services Authority diversification regarding the diversity of the directors, then the industry differences require directors to have certain expertise.

The carbon management strategy does not have a positive effect on environmental performance. The company's carbon management strategy is almost the same quality in environmental management. The study also failed to prove the positive influence between environmental management systems on carbon management strategies. This is because companies that do not have an ISO 14000 certificate or from the Ministry of Environment also have a very good carbon management strategy because there are other international certificates owned such as ISO 50001 regarding energy management which require companies to pay attention to greenhouse gas mitigation so that companies also pay attention to sustainability environment.

Likewise, the number of director meetings does not have a positive effect on the carbon management strategy because every directors meeting does not discuss carbon management strategies but rather discusses other matters such as the performance of companies that benefit the company more. This study did not succeed in proving a positive influence between the directors' educational background on carbon management strategies. This is due to the fact that directors with accounting education backgrounds are few in number so they do not focus on carbon management strategies but rather focus on finance and reporting.

In this study it was also found that environmental committees had a positive effect on carbon management strategies. This is because the environmental committee has formed a carbon management strategy. In the absence of an environmental committee, the company cannot create a carbon management strategy.

Intervening variables mediate the influence between environmental management systems, environmental committees, number of director meetings and director's educational backgrounds on environmental performance. The examine results were directly not positive, but after the carbon management strategy as a mediator these independent variables all had a positive effect on environmental performance. Thus, companies that have carbon management strategies will have better environmental performance than companies that do not have a carbon management strategy.

\subsection{Limitations}

The limitation in this study is the limited number of companies that publish sustainability reporting. In addition to the limited number of years studied, researcher only used 3 years of research starting in 2014 until 2016. Then, $\mathrm{CO} 2$ disclosure as an environmental performance even though the carbon management strategy applied by the company was used to reduce $\mathrm{CO} 2$ levels annually so that government goals in gas emissions greenhouses ratified by the government can be achieved. Furthermore, no mandatory disclosures for sustainability reports for 
companies listed on the IDX are very limited. Finally, there is unavailability of $\mathrm{CO} 2$ data for all companies that disclose sustainability reports so that there are samples that cannot be used.

\subsection{Implications}

This research can have implications for managers, regulators, practitioners and academics. Company leaders are expected to implement a carbon management strategy to improve the company's environmental performance. It is better for all companies, especially those listed on the IDX, to have sustainable reports to be more obedient and participate in realizing government regulations regarding greenhouse gas mitigation. Practitioners and the public should be involved in taking care of the environment by reducing greenhouse gases for the sake of the preservation of the earth. For further researchers who want to examine the company's environmental performance and carbon management strategies can use environmental costs and corporate codes of ethics in creating better environmental performance.

\section{References}

Anandale D, Morrison-saunders,A and Bouma,G. "The Impact of voluntary environmental protection instrument on company environmental performance". 2004.

Carol-Ann Tetrault Sirsly. "Sustainability measures: a stakeholder focus beyond shareholders". World Journal of Enterpreneurship management and sustainable development. Volume : 11. Issues :1, 2015.

Clarkson, Peter M., Li, Yue ., Richardson, Gordon D., Vasvari, Florin P. "Revisiting the Relation Between Environmental Performance and Enviromental Disclosure: An Emperical Analysis". CAAA 2006 Annual Conference paper Rotman School of Management working paper no.07-07.

Dwi, Septiadika and Ningrum Kartika. "Pengaruh Karakteristik Dewan Direksi terhadap Kinerja Keuangan Bank Syariah di Indonesia". Fakultas ekonomi dan Bisnis Islam, Perbankan Syariah. 2016.

Giannarakis,G., Konteos, G., Sariannidis, N and Chaitidis. "The Relation between Voluntary Carbon Disclosure and Enviromental Performance The case of S\&P 500”. International Journal of Law and Manajement vol. 59 No.6.pp.784-803. 2017.

Irwhantoko, Basuki. Carbon Emission Dislosure. Studi pada perusahaan manufaktur Indonesia . Jurnal Akuntansi dan Keuangan. Vol 18 No.2 November 2016., 92-104 ISSN 1411-0288.

Kristaung, R and Augustine,Y. "Metodologi Penelitian Bisnis dan Akuntansi". Edisi Dua. Dian Rakyat Jakarta.2018.

Lash, J. and Wellington, F. “Competitive advantage on a warming planet”, Harvard Business Review, Vol. 85, pp. 94-102. 2007.

Melayk, S.A., Sroufe, R.P. and Calantone, R. "Assessing the impact of environmental management systems on corporate and environmental performance", Journal of Operations Management, Vol. 21 No. 3, pp. 271-285. 2003.

Moini, H., Sorensen, O.J and Kristiansen, E.S. “Adoption of green strategy by Danish Firm”.Sustainability Accounting, Management and policy Journal, Vol 5 issues:2,pp.197-223. 2014.

Montiel, I dan Husted, W.B. "The Adoptions of voluntary Environment management Programs in Mexico: First Mover as Institutional Enterpreneurs". Journal of Business Ethics 88:349-363 DOI 10.1007/s10551-0090282-y. 2009.

Nartey Edward. "Determinant of carbon management accounting adoption in Ghanaian Firms".Meditary Accounting Research Vol.20 No.1. pp.88-121. 2018.

Rahayu, Sri and Nugriho, Samiaji "Pengaruh Komposisi dan Pendidikan Dewan Perusahaan terhadap Nilai Perusahaan dalam Pelaksanaan Good Corporate Governance pada Badan Usaha Milik Negara yang Terdaftar di Bursa Efek Jakarta".Jurnal Manajemen Bisnis Sriwijaya vol.12 No.4 Desember 2014.

Rankin, M., Windsor,C., Wahyuni, D. "An Investigation of Voluntary Corporate Greenhouse Gas Emissions Reporting in a Market Governance system: Australian Evidence". Accounting, Auditing and Accountability Journal. Vol 24. No.8,pp 1037-1070. 2011.

Sudibyo, YA. "Carbon Emission Disclosure: does it matter". The 4th Internationl Seminar on Sustainable Urban Development. IOP Conf. Series: Earth and Environtment Science 106 (2018) 012036. doi:10.1088/17551315/106/1/012036.

Wahyuni, D. and Ratnatunga, J. "Carbon strategies and management practices in an uncertain carbonomic environment - lessons learned from the coal-face", Journal of Cleaner Production, Vol. 96 No. 1, pp. 397406.2015.

Yunus Somaiya., Elijido-Ten Envangeline and Abhayawansa .S. "Determinant of Carbon Management Strategy Adoption Eviden from Australia's Top 200 Publicy Listed Firms”.'Manajerial Accounting Journal Vol.31 No.2.pp.156-179. 2016

Datacenteraid.blogspot.com Data Center showing posts with the label "laporan keberlanjutan"

Https://sains.kompas.com/read/2017/07/12/080800823/71.persen.gas.rumah.kaca.global.ternyata.berasal 
dari.100.produsen.

Https://www.coursehero.com dapat diukur dengan menghitung total aset total penjualan jumlah tenaga kerja Https://www.ojk.go.id Paris Agreement Https://www.scribd.com Teori Stakeholder Bab 8 Deegan.

Https://www.voaindonesia.com/a/pbb-emisi-gas-rumah-kaca-tertinggi-dalam-800-ribu-tahun/4093328.html PBB:

Emisi Gas Rumah kaca tertinggi dalam 800 ribu tahun.

Pustakabakul.blogspot.com $>2014 / 04$. Pengertian Kinerja dan Pengukuran Kinerja Lingkungan

POJK nomor 33/POJK.04.2014

Sra.ncsr-id.org tahun 2014, 2015 dan 2016

Www.ojk.go.id Kyoto Protocol to the United Nations Framework Convention on Climate Change

Www.mongabay.co.id>cop-18 COP-18 Doha: Negara-Negara Maju Lepas Tangan dari Protokol Kyoto

Www.pengertianmenurutparaahli.net $>$. Pengertian Legitimasi-pengertian Menurut Para Ahli 